\title{
Parasite body volume and infracommunity patterns in the southern pomfret Brama australis (Pisces: Bramidae)
}

\author{
Volumen corporal del parásito y patrones infracomunitarios en la reineta Brama \\ australis (Pisces: Bramidae)
}

MARIO GEORGE-NASCIMENTO, FÉLIX GARCÍAS \& GABRIELA MUÑOZ

Facultad de Ciencias, Universidad Católica de la Santísima Concepción, Casilla 297, Concepción,
Chile; e-mail: mgeorgen@ucsc.cl

\begin{abstract}
The patterns of infracommunity descriptors (diversity, dominance, abundance) are compared when calculated with the number and body volume of the parasites in a sample of 26 southern pomfrets Brama australis collected in the area off Talcahuano, Chile. No numerical infracommunity descriptor was correlated with its corresponding volumetric descriptor. This single result casts doubts about the general validity of the infracommunity patterns described in the literature so far, because they are almost exclusively based on the number of parasite individuals per individual host, restricting communication with ecologists that use density or other measures of ecological abundance.
\end{abstract}

Key words: parasite body volume, infracommunity patterns, host body size, Brama australis, Chile.

\section{RESUMEN}

Los patrones de los descriptores infracomunitarios (diversidad, dominancia, abundancia) son comparados cuando son calculados en base a los números o al volumen corporal de los parásitos en una muestra de 26 reinetas Brama australis recolectadas en el área de Talcahuano, Chile. Ningún descriptor infracomunitario calculado con el número de parásitos estuvo correlacionado con los basados en el volumen corporal de los parásitos. Este resultado siembra dudas acerca de la validez general que pueden tener los patrones infracomunitarios registrados en la literatura ya que están casi exclusivamente calculados con el número de parásitos por individuo hospedador, lo que dificulta aún más la comunicación con los ecólogos, que usan la densidad u otras medidas de abundancia ecológica.

Palabras clave: volumen corporal del parásito, patrones infracomunitarios, tamaño corporal del hospedador, Brama australis, Chile.

\section{INTRODUCTION}

Parasite communities are usually described in ways that only take into account the numbers of individuals and species. However, there are complementary ways, usually neglected, to measure the information and to search for community patterns. It is here thought that the total parasite biomass in an average host individual of any given species reflects, in one way or another, their energy demands (of the host and the parasites). Consequently, we here include the body volume of parasites, as an estimate of their biomass. The body size of the parasites has been considered only recently when assessing the relationships with the prevalence and parasitic intensity in 89 helminth species and copepod parasites of fish (acanthocephalans, digeneans and copepods, see Poulin 1999). The few published results point out that the body size of the parasites could be an important factor in determining aspects of the parasitic abundance and its distribution, including the aggregation. It has been debated if infracommunities are strongly structured by biotic factors such as competition and are therefore more predictable than others (Poulin 1998). In addition, many studies establish relationships among the infracommunity descriptors (abundance, diversity, dominance) and the ontogenetic stage (= size, age) of the host.

Pomfrets Brama spp. inhabit tropical and temperate waters (Paulin 1981), and have a wide geographical distribution, although preferably they are in the open oceanic area, sometimes living at greater depths (Mead 1972). The southern pomfret Brama australis Valenciennes, 1836 feeds 
mainly on euphausiids (Muñoz et al. 1995), which would be the main intermediary hosts of endoparasitic taxa.

\section{MATERIAL AND METHODS}

The infracommunities of parasites are the metazoan assemblages found in each host individual. They were obtained from 26 hosts sampled in September 1998 near Talcahuano (36 $41^{\circ}$ ' S, $73^{\circ} 06^{\prime} \mathrm{W}$ ), Chile. Southern pomfrets (nine males and 17 females) were preserved at $-20^{\circ} \mathrm{C}$ until the census of each infracommunity. The procedures of collecting parasites are described in GeorgeNascimento \& Iriarte (1989). Total body length (cm) was determined for each host. The taxonomic determination of the hosts followed Pavlov (1991). The parasites were determined according to Schmidt (1986) for the cestodes, Zdzitowiecki (1991) for the acanthocephalans, Yamaguti (1961) for the nematodes, Gibson (1996) for the trematodes, Kabata (1988) for the copepods, and Avdeyev (1992) for the isopods. All the parasites were fixed in $10 \%$ formalin
Each parasitosis was described by means of the prevalence (percent of examined individuals that are parasited), the numerical abundance (number of parasite individuals per host, see Bush et al. 1997), and the volumetric abundance (volume of parasites per host, in $\mathrm{mm}^{3}$ ). The body volume of each taxon was approximated. For the small parasites, body volume was determined by measuring maximum length and diameter, assuming a regular cylindrical body shape. For large-sized parasites or those of irregular shape, body volume was determined by volume displacement. All specimens were measured in species with less than 30 specimens collected, and a sample of ca. 30 in the most common ones.

The taxonomic richness of an infracommunity is the number of parasitic taxa per host individual, regardless of whether it is measured in numbers or in volume. The total numerical abundance is the total number of parasite individuals per host, or the sum of the numerical abundances of each taxon divided by the number of hosts examined. The total volumetric abundance is the volume in $\mathrm{mm}^{3}$ of parasites in a host, or the sum of the multiplications of the mean individual body volume of each taxon

TABLE 1

Prevalence $(\mathrm{P}, \%)$, total parasite numbers $(\mathrm{N})$, mean body volume of each parasite taxon $(\mathrm{V}$, in $\mathrm{mm}^{3}$ ), numerical abundance (NA) and volumetric abundance (VA, in $\mathrm{mm}^{3}$ ) of 15 parasitic taxa found in 26 southern pomfrets Brama australis collected off Talcahuano, Chile

Prevalencia (P \%), número total de parásitos recolectados (N), volumen corporal promedio de cada taxon parasitario $\left(\mathrm{V}\right.$, en $\mathrm{mm}^{3}$ ), abundancia numérica (NA) y abundancia volumétrica (VA, en $\mathrm{mm}^{3}$ ) de 15 taxa parasitarios encontrados en 26 reinetas Brama australis recolectadas cerca de Talcahuano, Chile

\begin{tabular}{|c|c|c|c|c|c|c|}
\hline Taxa & & $\mathrm{P}$ & $\mathrm{N}$ & $\mathrm{V}$ & NA & VA \\
\hline \multicolumn{7}{|l|}{ Acanthocephala } \\
\hline \multicolumn{6}{|l|}{ Platyhelminthes } & $<0.1$ \\
\hline Tetraphyllidae gen. sp. & (1) & 15 & 58 & 0.1 & 2.2 & 0.2 \\
\hline Koellikeria filicollis & (2) & 39 & 16 & 42.0 & 0.6 & 25.8 \\
\hline Didymozoon sp. & $(2)$ & 4 & 1 & 23.9 & $<0.1$ & 0.9 \\
\hline Hepatoxylon trichiuri & $(1)$ & 58 & 34 & 350.0 & 0.9 & 323.1 \\
\hline Nybelinia sp. & (1) & 8 & 2 & 0.5 & 0.1 & $<0.1$ \\
\hline Larval cestode a & (1) & 31 & 9 & 0.2 & 0.3 & $<0.1$ \\
\hline Tripanorhyncha sp. a & (1) & 8 & 4 & 7.1 & 0.1 & 1.1 \\
\hline Tripanorhyncha sp. b & (1) & 4 & 1 & 6.5 & $<0.1$ & 0.2 \\
\hline Accacoelium sp. & $(2)$ & 4 & 1 & 5.3 & $<0.1$ & 0.2 \\
\hline \multicolumn{7}{|l|}{ Nematoda } \\
\hline Contracaecum sp. & $(1)$ & 73 & 53 & 0.2 & 2.0 & 0.4 \\
\hline Anisakis sp. & (1) & 31 & 9 & 5.2 & 0.3 & 1.8 \\
\hline \multicolumn{7}{|l|}{ Arthropoda } \\
\hline Hatschekia conifera & (3) & 100 & 1,534 & 1.7 & 59.0 & 100.3 \\
\hline Lepeophtheirus sp. & (3) & 8 & 2 & 7.2 & 0.1 & 0.5 \\
\hline Ceratothoa sp. & (3) & 46 & 16 & 250.0 & 0.6 & 153.8 \\
\hline Total & & & 1,745 & & & \\
\hline
\end{tabular}

(1) = larval endoparasite; (2) =adult endoparasite; (3) = ectoparasite 

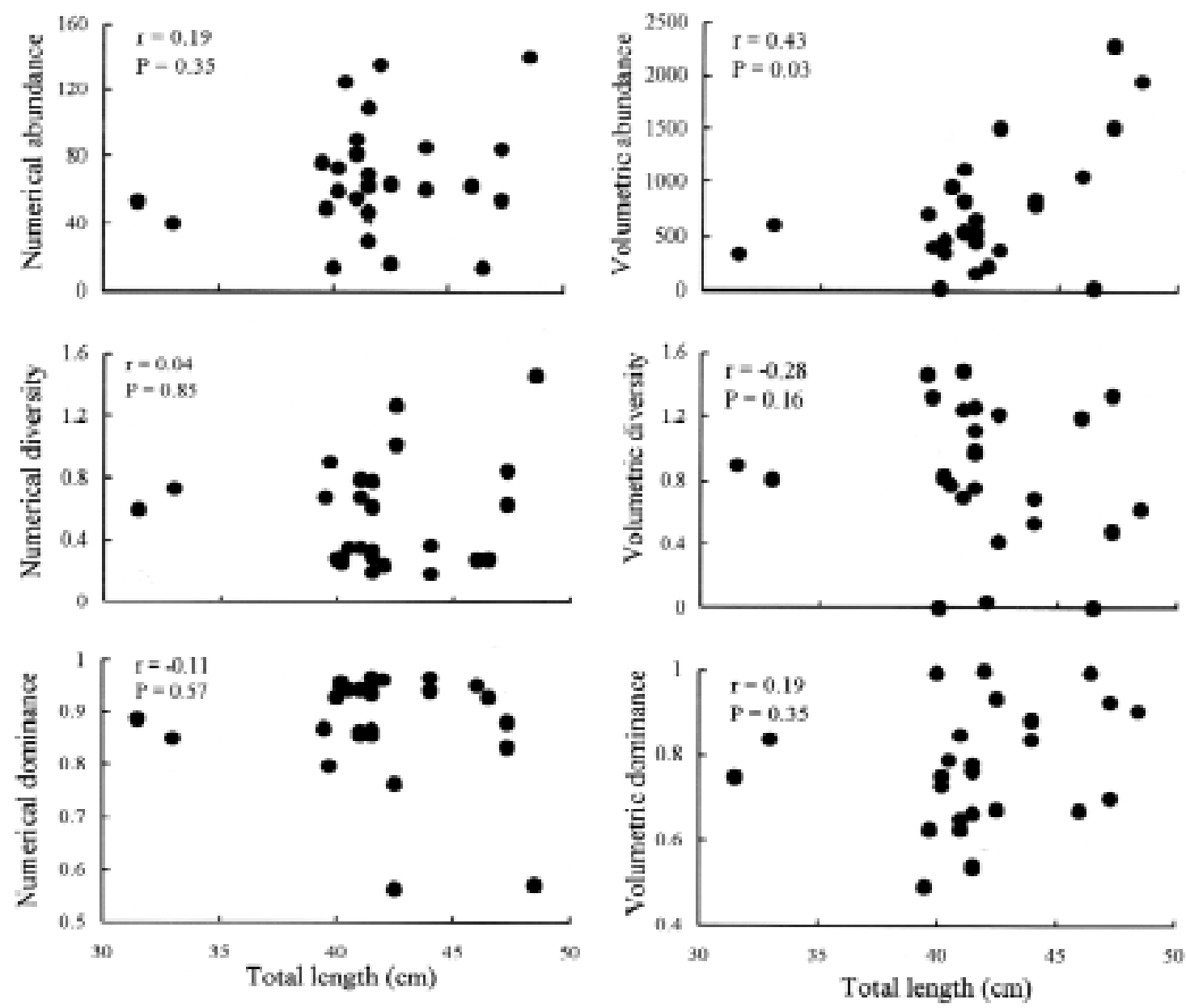

Fig. 1: Relationship between numerical and volumetric infracommunity descriptors (abundance, diversity, dominance) with the host's body length $(\mathrm{cm})$.

Relación entre los descriptores numéricos y volumétricos de las infracomunidades de parásitos de la reineta (abundancia, diversidad, dominancia), con la longitud total del hospedador.

times its numerical abundance. Two other infracommunity descriptors were calculated, both based on the number and the volume of the parasites: the diversity (according to the index of Brillouin, see Magurran 1988) and the dominance, as the ratio between the abundance of the most numerous taxon (or that of largest body size) and the total.

The potential importance of the ontogeny of the host on the variations in these infracommunity quantitative descriptors was evaluated using Spearman's rank correlation analyses between the total body length of the host and the infracommunity descriptors (numerical and volumetric abundance of each parasitic taxon, diversity and dominance), and between the numerical and volumetric infracommunity descriptors.

\section{RESULTS AND DISCUSSION}

The total body length of the 26 southern pomfrets ranged between 31.5 and $48.5 \mathrm{~cm}$. A total of 1,745 parasites belonging to 15 taxa were collected. Of them, nine were larval endoparasites, three were adult endoparasites and three were ectoparasites (Table 1). All the specimens harbored at least two parasitic taxa. The most prevalent and abundant taxon was the ectoparasite Hatschekia conifera. The less prevalent and abundant taxa were Didymozoon sp., Accacoelium sp. and Trypanorhyncha sp. b. The largest parasitic taxa were Hepatoxylon trichiuri and Ceratothoa sp. (Table 1). On the average, each host had ca. 67 parasite individuals, approximately equivalent to $742 \mathrm{~mm}^{3}$. The southern pomfrets harbored nine out of 12 endoparasitic taxa that were at larval stage, 
indicating that is likely to be preyed upon by mammals and sharks. The record of Didymozoon sp. and Koellikeria filicollis constitute the first in the southeastern Pacific, although both taxa have been reported in Brama sp. and B. japonica, respectively (Yamaguti 1961). Hepatoxylon trichiuri was the only taxon showing a significant increase of its abundance with the total body length of the host $\left(\mathrm{r}_{\mathrm{s}}=0.57, \mathrm{P}<0.01\right)$. This may reflect its accumulation since this cestode is located in the coelomic cavity of the host.

The total volumetric abundance is the only infracommunity descriptor significantly and positively correlated with the body length of the host (Fig. 1). The numerical and volumetric infracommunity descriptors don't keep significant correlations with each other (Fig. 2). For example,
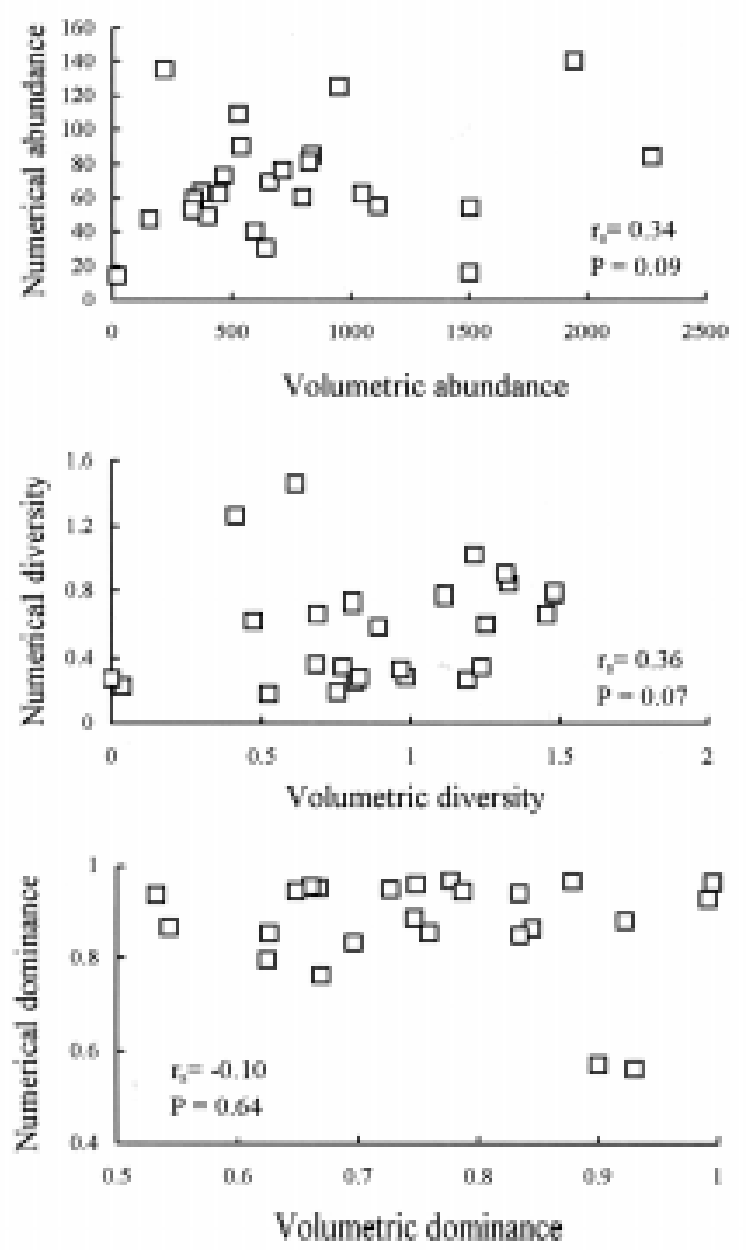

Fig. 2: Relationship between numerical and volumetric infracommunity descriptors (abundance, diversity, dominance) in the southern pomfret.

Relación entre los descriptores numéricos y volumétricos de las infracomunidades de parásitos de la reineta (abundancia, diversidad, dominancia). the copepod Hatschekia conifera was the most prevalent and abundant parasite. Hepatoxylon trichiuri, however, was not very numerous and had the largest body volume of all the taxa (Table 1 ), being more than three times larger than $H$. conifera and twice the size of Ceratothoa.

These results point out that a little abundant but voluminous taxon could generate or vanish infracommunity patterns based on number of parasites alone. This would also happen at other community levels, however, the relationship between parasite body volume and density has not yet been examined at any community level in parasitological research. We consider more complete and more inclusive the community description based on the body volume of parasites because it necessarily incorporates the numerical abundance. In a similar vein, it is considered that the expression of parasite density should include the body mass of the host and the parasites. In this way, energetic approaches could be made and the extent to which a relationship between body size and density holds, it could be researched at different community levels. Finally, this approach reveals that there are several other "ecological" terms yet to define (Bush et al. 1997), when community biomass or abundance are the prisma through which the community patterns are looked for (see Tilman 1999). Hopefully then, temporal and spatial persistence of parasite communities will show new perspectives to explore.

\section{ACKNOWLEDGMENTS}

This study was supported by Grants FONDECYT 1980442 and FONDAP, Program 3. We wish to thank Dr. Raúl Castro Romero by taxonomic identification of copepods, and Dr. Rodney Bray by taxonomic identification of trematodes.

\section{LITERATURE CITED}

AVDEYEV VV (1992) On the possible use of parasitic isopods as bioindicators of the migratory routes of horse mackerels in the Pacific Ocean. Journal of Ichthyology 32: 14-21.

BUSH AO, KD LAFFERTY, JM LOTZ \& AW SHOSTAK (1997) Parasitology meets ecology on its own terms: Margolis et al. revisited. Journal of Parasitology 83: 575-583.

GEORGE-NASCIMENTO M \& JL IRIARTE (1989) Las infracomunidades de parásitos metazoos del chancharro Helicolenus lengerichi Norman, 1937 (Pisces, Scorpaenidae): un ensamble no interactivo de especies. Revista Chilena de Historia Natural 62: 217-227. 
GIBSON DI (1996) Trematoda. In: Margolis L \& Z Kabata (eds) Guide to the parasites of fishes of Canada. Part IV. Canadian Special Publication of Fisheries and Aquatic Sciences 124: 1-373.

KABATA Z (1988) Crustacea. In: Margolis L \& Z Kabata (eds) Guide to the parasites of fishes of Canada. Part II. Canadian Special Publication of Fisheries and Aquatic Sciences 101: 1-184.

MAGURRAN AE (1988) Ecological diversity and its measurement. Princeton University Press, Princeton, New Jersey. 175 pp.

MEAD GW (1972) Bramidae. Dana-Report 81: 1-175.

MUÑOZ G, N CORTÉS, M ARRIAZA \& C OYARZÚN.(1995) Alimentación de una especie poco conocida, Brama australis Valenciennes, 1836 (Pisces: Bramidae) en la costa centro-sur de Chile. Biología Pesquera (Chile) 24: 51-55.

PAULIN CD (1981) Fishes of Family Bramidae recorded from New Zealand. New Zealand Journal of Zoology 8: 25-31.

PAVLOV YUP (1991) Information on morphometrics and ecology of pomfrets of genus Brama inhabiting the Southeastern Pacific Ocean. Journal of Ichthyology 31: 120-124.

Associate Editor: B. Dyer

Received March 28, 2002; accepted July 30, 2002
POULIN R (1998) Evolutionary ecology of parasites: from individuals to communities. Chapman \& Hall, New York, New York. 211 pp.

POULIN R (1999) Body size vs abundance among parasite species: positive relationship? Ecography 22: 246250 .

SCHMIDT GD (1986) CRC Handbook of tapeworm identification. CRC Press, Inc., Boca Raton, Florida. $675 \mathrm{pp}$

TILMAN D (1999) The ecological consequences of changes in biodiversity: a search for general principles. Ecology 80: 1455-1474.

YAMAGUTI S (1961) Systema Helminthum. The nematodes of vertebrates. Volume 3. Interscience Publishers, New York, New York. 329 pp.

ZDZITOWIECKI K (1991) Antarctic Acanthocephala. Volume 3. Koeltz Scientific Books, Koeningtein, Germany. 116 pp. 